\title{
Pelatihan Pembuatan Bata Ringan Kepada Home Industri Batu Bata Konvensional Guna Mendukung Program Pemerintah 1 Juta Rumah Bersubsidi Traning of Making bata ringan to Conventional Batu bata Industry Home to Support Government's Program of 1 Million Subsidized Houses
}

\author{
Denny Akbar Tanjung1) \& Sirmas munte ${ }^{2)}$ \\ 1)Program Studi Agroteknologi, Fakultas Pertanian, Universitas Medan Area \\ 2) Program Studi Teknik Industri, Fakultas Teknik, Universitas Medan Area
}

Diterima: 25 Januari 2019; Disetujui: 13 Maret 2020; Dipublish: 23 Maret 2020

*Coresponding Email: Dennyakbartanjung@staff.uma.ac.id/munthe001.yahoo.co.id

\section{Abstrak}

Pengusaha batu bata merah konvensional dimana dari hari ke hari angka permintaan pasar terus menurun ini diakibatkan oleh keputusan konsumen memilih batu bata ringan dari pada batu bata merah. Kelebihan-kelebihan yang ditawarkan batu bata ringan ini menjadi alasan konsumen untuk berpaling. Selain angka penjualan menurun, mahalnya tanah liat karena diperoleh dari luar wilayah desa dan tingginya biaya produksi karena memakan waktu yang lama dalam proses memproduksi batu bata merah membuat pengusaha batu bata merah konvensional semakin menjerit. Keadaan ini mengharuskan pengusaha batu bata merah konvensional beralih memproduksi batu bata ringan. Namun, didalam peralihannya ke batu bata ringan pengusaha menemui beberapa hambatan dan rintangan. Seperti belum adanya keterampilan dalam pembuatan batu bata ringan, tidak diperkenalkannya teknologi serta wilayah pemasaran yang masih kecil. Dengan kegiatan pengabdian kepada masyarakat ini kami ingin mendampingi pengusaha batu bata merah konvensional untuk membantu mencari solusi segala masalah yang dihadapi dalam peralihan produknya. Kegiatan ini dilaksanakan pada home industri Bapak Eka Prayogi dan Bapak Ahmad selama 3 Bulan dan akan dievaluasi terhadap mutu produk bata ringan yang dihasilkan dan permintaan pasar terhadap batu bata ringan.

Kata Kunci: Bata Bata Merah, Batu Bata Ringan, Konvensional, Modern.

\begin{abstract}
The conventional red brick entrepreneur where from day to day the market demand figures continue to decline is due to the decision of consumers to choose lightweight bricks rather than red bricks. The advantages offered by lightweight bricks is a reason for consumers to turn away. In addition to declining sales figures, the high cost of clay because it is obtained from outside the village area and the high cost of production because it takes a long time in the process of producing red bricks makes conventional brick makers more screaming. This situation requires conventional red brick entrepreneurs to switch to producing lightweight bricks. However, in its transition to lightweight bricks, entrepreneurs encountered several obstacles and obstacles. As there are no skills in making lightweight bricks, technology is not introduced as well as marketing areas are still small. With this community service, we want to assist conventional red brick entrepreneurs to help find solutions to all problems encountered in the transition of their products. This activity was carried out at Mr Eka Prayogi and Mr Ahmad's home industry for 3 months and will be evaluated on the quality of light brick products produced and the market demand for light bricks.
\end{abstract}

Keywords: Red Brick, Lightweight Brick, Conventional, Modern.

How to Cite: Tanjung, D.A. \& Munte, S. (2020). Pelatihan Pembuatan Bata Ringan Kepada Home Industri Batu Bata Konvensional Guna Mendukung Program Pemerintah 1 Juta Rumah Bersubsidi. Journal of Education, Humaniora and Social Sciences (JEHSS). 2(3): 578-582.

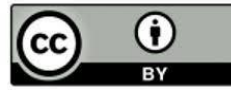




\section{PENDAHULUAN}

Salah satu upaya untuk meningkatkan potensi ekonomi di daerah adalah menghidupkan sektor industri termasuk industri rumah tangga "Industri telah diakui sebagai sektor penunjang utama pembangunan regional. Kegiatan ini memang beralasan, mengingat banyaknya daerah yang ditunjang oleh industri, ternyata memperlihatkan hasil yang cukup menggembirakan “, Kartanto, (2012). Keberhasilan dari Pembangunan daerah dapat dilihat dari terciptanya kesempatan kerja yang luas dan merata. Pembangunan pabrik-pabrik disuatu daerah dengan sendirinya akan membuka lapangan pekerjaan baru, “jadi, masalah ketenagakerjaan harus dipecahkan dengan melihat aspekapsek yang lainnya. Diantaranya adalah perluasan sektor-sektor padat karya, seperti industri kecil, sektor jasa, industri rumah tangga, kerajinan rakyat dan sebagainya", (Sukadji, 2010)

Batu bata merupakan salah satu bahan bangunan yang terbuat dari tanah liat dengan atau tanpa campuran bahan lain, kemudian dibakar pada suhu tinggi sampai berwarna kemerah-merahan. Batu bata yang baik terdiri atas pasir (silika) dan tanah liat (alumina), yang dicampur dengan perbandingan tertentu dan bila diberi sedikit air menjadi bersifat plastis, sehingga dengan mudah tanah dapat dicetak. Penggunaan bata memiliki keuntungan karena memungkinkan digunakan sebagai beberapa fungsi yang pada struktur portal tidak mungkin dilakukan. Dinding bata berfungsi juga sebagai komponen struktur penyekat ruangan, William Swendy Sinagai dan Rio Hotman Partogian, 2016.

Selain batu bata merah, batu bata ringan juga banyak digunakan sebagai bahan bangunan. Sejak terciptanya batu bata ringan yang merupakan inovasi dari batu bata merah ada yang menganggap ini adalah abad baru sebagai penerapan teknologi untuk meninggalkan cara-cara tradisional menuju modernisasi dalam proses pembuatan batu bata karena teknologi komposit dan mesin digunakan dalam proses ini. Proses produksinya yang simpel dan tidak memakan waktu yang lama dan bahan baku yang mudah didapatkan menjadi alasan untuk beralih ke produk ini. Namun, bagi yang tidak bisa menerima hal-hal baru dengan tetap mempertahankan tradisi lama sebagai warisan nenek moyang leluhur, ini adalah merupakan ancaman bagi kelangsungan usaha bata batanya. 
Denny Akbar Tanjung \& Sirmas Munte. Pelatihan Pembuatan Bata Ringan Kepada Home Industri Batu

Ditinjau dari segi persediaan tanah liat pengusaha Bapak Eka Prayogi dan Pak Ahmad saat ini sulit untuk mendapatkannya, lahan tanah liat disekitar kawasan pabrik yang sebelumnya dijadikan andalan untuk pembuatan batu bata ini kini sudah mulai habis dikeruk setiap harinya. Alhasil, pengusaha harus mendatangkan dari luar daerah. Bahan bakar juga menyumbang permasalahan yang dihadapi karena kayu bakar harganya tidak tetap. Cuaca juga ikut andil dalam kelancaran produksi batu bata ini. Disaat cuaca terik proses pengeringan dan pemasakan dalam tungku dapat selesai sesuai jadwal. Namun, jika musim hujan waktu proses produksi bisa molor sampai \pm 10 hari. Selain itu, abnormal quality terjadi $5 \%$ akibat dari tidak stabilnya temperatur saat pemasakan sehingga batu bata ada yang terlalu masak (hitam dan retak) dan ada juga tidak masak (gampang pecah atau rapuh). Tidak stabil ini diakibatkan tidak dijaganya api selama proses pemasakan.

Penurunan penjualan batu bata juga ikut memperburuk keadaaan dimana para konsumen sudah beralih ke batu bata ringan yang katanya mempunyai banyak kelebihan dibandingkan dengan bata merah baik dari segi harganya maupun penghematan bahan dari plasternya.

Dari uraian diatas dapat kami rumuskan bahwa permasalahan yang dihadapi oleh pengusaha batu bata saat ini adalah: 1) Harga tanah liat mahal (karena didatangkan dari luar daerah); 2) Bahan bakar seperti kayu mahal dan sulit didapat; 3) Cuaca yang tidak menentu memperlambat proses pengeringan; 4) Beralihnya konsumen dengan menggunakan batu bata ringan mengurangi orderan selama ini; 5) Tidak adanya bimbingan dan pelatihan pembuatan batu bata ringan menghambat peralihannya dari produk batu bata merah menjadi batu bata ringan

\section{METODE PELAKSANAAN}

Tim mempersiapkan hal-hal yang diperlukan dalam pelaksanaan kegiatan pengabdian masyarakat yaitu sebagai berikut: 1) Melakukan beberapa percobaan tentang pembuatan batu bata ringan; 2) Melakukan persiapan alat dan dan bahan yang dibutuhkan; 3) Menyusun materi pelatihan penyusunan laporan keuangan

Kegiatan ini dilaksanakan dipabrik Batu bata milik Pak Eka dan Pak Ahmad yang terletak di jalan Sidaurip Desa Beringin Deliserdang Sumatera Utara. Pesertanya adalah Bapak Eka Prayogi dan Pak Ahmad Beserta seluruh karyawan beserta karyawan/i.Tim 
Pengabdian terdiri dari Ketua, anggota dan dibantu 2 orang mahasiswa.Secara garis besar masalah yang dihadapi mitra yaitu sulitnya mendapatkan bahan baku tanah liat, kayu untuk bahan bakar, cuaca yang tidak menentu, penurunan penjualan batu bata ringan akibat masuknya produk baru yaitu batu bata ringan dan tidak mempunyai buku laporan keuangan sebagai salah satu syarat untuk memperoleh kredit dari bank . Solusi yang tim tawarkan dalam mengatasi masalah tersebut kepada mitra adalah: 1) Memperkenalkan batu bata ringan sebagai produk inovasi dari batu bata merah, menjelaskan kelebihan dan kekurangan batu bata ringan; 2) Menjelaskan benefit yang didapat dari penjualan batu bata ringan oleh tim ekonomi; 3) Melaksanakan pelatihan pembuatan batu bata ringan; 4) Dari dana hibah PKM tim akan menyisikan dana untuk memberi bantuan alat untuk proses pembuatan batu bata ringan.

\section{HASIL DAN PEMBAHASAN}

Dari hasil kegiatan dapat dilaporkan bahwa: 1) Kegiatan berjalan lancar sesuai dengan jadwal yang telah disepakati antara TIM dan Mitra; 2) Dalam pelatihan pembuatan batu bata ringan mitra sangat antusias mengikutinya ini dapat dilihat dari banyaknya pertanyaan yang diajukan ke instruktur; 3) Setelah mengikuti pelatihan mitra berminat untuk uji coba pembuatan batu bata ringan sebagai produk baru.

Kalkulasi Biaya Produksi dan Laba untuk $1 \mathrm{~m} 3$ bata :

\begin{tabular}{|l|l|l|l|}
\hline No. & Uraian & Banyaknya & Jumlah \\
\hline 1 & Semen & 6 sak & Rp. 360.000 \\
\hline 2 & Pasir & $500 \mathrm{~kg}$ & Rp. 70.000 \\
\hline 3 & Foam Agent & $0,8 \mathrm{~kg}$ & Rp. 20.000 \\
\hline 4 & Pemakaian Listrik & & Rp. 10.000 \\
\hline 5 & Ongkos Pekerja & Borongan & Rp. 50.000 \\
\hline 6 & Ongkos Kirim & & Rp. 40.000 \\
\hline 7 & Depresiasi + Perawatan dll & & Rp. 50.000 \\
\hline Total Biaya Produksi per $\mathrm{M}_{3}$ & & Rp. 600.000,-- \\
\hline Harga jual per M3 & Rp. 700.000,- \\
\hline \multicolumn{2}{|l|}{ Keuntungan kotor per $\mathrm{m}_{3}$} & Rp. 100.000,- \\
\hline
\end{tabular}

Estimasi laba kotor untuk produksi/bulan (25 hari kerja)

Kapasitas 5 m3/hari Rp. 12.500.000,-

Kapasitas 10 m3/hari Rp. 25.000.000,-

Kapasitas 20 m3/hari Rp. 50.000.000,-

Penggunaan semen 5 - 6 sak tergantung dari kualitas pasir yang digunakan. 
Denny Akbar Tanjung \& Sirmas Munte. Pelatihan Pembuatan Bata Ringan Kepada Home Industri Batu

Hitungan diatas merupakan hitungan yang konservatif.

Harga material yang digunakan merupakan perhitungan berdasarkan harga-harga di Medan. (Mei 2019).

\section{SIMPULAN}

Dari hasil kegiatan pengabdian masyarakat diatas dapat kami ambil kesimpulan bahwa kegiatan berjalan sesuai dengan jadwal yang telah disepakati, pelaksanaan pembuatan bata ringan telah berhasil dilakukan, mitra sangat antusias dalam memperhatikan setiap tahapan pembuatan bata ringan.

\section{UCAPAN TERIMA KASIH}

Pada kesempatan ini tim PKM ingin mengucapkan terima kasih yang sebesarbesarnya kepada Pengurus Yayasan Pendidikan Haji Agus Salim Universitas Medan Area dan Rektor Universitas Medan Area yang telah memberi dukungan baik dalam bentuk moril maupun materil sehingga Program Pengabdian Kepada Masyarakat dapat berjalan sesuai dengan yang direncanakan.

\section{DAFTAR PUSTAKA}

ASTM International (An American National Standard). (2002). ASTM - C144 - 04, Standard Specification for Aggregate for Masonry Mortar. West Conshohoken, PA 19428 - 2959, United States.

Badan Standar Nasional, (2002). SK-SNI 03-6861.1 Spesifikasi Bahan Bangunan, Jakarta.

Kartanto Mardi, (2012), Pembangunan Perindustrian Di Indonesia, Erlangga, Jakarta

Simamora Bilson, (2013), Riset Pemasaran, (Falsafat, Teori dan aplikasi, Rineka Cipta, Jakarta

Sukadji, (2010), Industri dalam Perkembangannya, Balai Pustaka, Jakarta

SII 0021-78. (1978). Mutu dan Cara Uji Bata Merah Pejal. Departemen Perindustrian.

V.Totok Noerwasito Dan Mas Santosa, 2016 “Pengaruh “Thermal Properties” Material Bata Merah Dan Batako Sebagai Dinding, Terhadap Efisien Enerji Dalam Ruang Di Surabaya”, Dimensi Jurnal Of Architecture and Built and Development

Sinaga, W.S. dan Partogian, R.H. (2016), Pengaruh Dimensi Ukuran Batu Bata Merah Dan Campuran Mortar Terhadap Karakteristik

Pasangan.Dinding.Http://Sipil.Studentjournal.Ub.Ac.Id/Index.Php/Jmts/Article/View/424

www. perumnas.co.id

http://bismakonstruksi.com/kelebihan-dan-kekurangan-menggunakan-bata-ringan/

https://id.wikipedia.org/wiki/Bata_ringan 